\title{
Ouabain Induced Stereotyped Behavior in Rats
}

\author{
D. L. W. DAVIDSON*, R.F.BUTTER WORTH, F. BÉLANGER, A. BARBEAU
}

SUMMARY: Stereotyped behavior was induced in rats with ouabain administered intraventricularly in doses of 2,3 and $4 \mu \mathrm{g}$ in $50 \mu \mathrm{l}$ saline. Haloperiodol reduced the stereotyped behaviour. Monoamine turnover sludies showed a reduction in concentration of norepinephrine in hippocampus and midbrain, an increase in norepinephrine turnover in the medulla oblongata and a reduction in dopamine turnover in the striatum. The interpretation of these finds is discussed. It is suggested that this model could be significant clinically as it demonstrates that impairment of $\mathrm{Na}^{+}-\mathrm{K}^{+}-A T P^{\prime}$ ase may result in behavioral abnormalities characterised by' stereotypy.

RÉSUMÉ: Des comportements stéréothés furent induits chez des rats avec de la ouabaine administrée de facon intraventriculaire en doses de 2, 3 et $4 \mu \mathrm{g}$ dans $50 \mu l$ de solution saline. L'halopéridol réduit ces mouvements stéréotypés. Des études sur le lurnover des monoamines montrent une réduction de la concentration en norépinéphrine dans l'hippocampe et le mésencéphale, une augmentation du urnover de la norépinéphrine dans le tronc cérébral et une réduction du turnover de la dopamine dans le striatum. Ce modèle pourrait être utile cliniquement car il démontre que latteinte de la $\mathrm{Na}^{+}-\mathrm{K}^{+}$. ATP'ase peut causer des anomalies de comportement caractérisces par de la sétéotypie.

\footnotetext{
From the Department of Neurobiology, Clinical Research Institute of Montreal.

*In reccipt of Peel Travelling fellowship. Present Address: Department of Neurology: Dundee Royal Infirmary. Dundec DDI 9ND. Scotland.

Reprint requests 10: Dr. André Barbeau. Clinical Rescarch Institute of Montreal, 110 Pine Ave. West.
} Montreal. H2W IR7, Canada.

\section{INTRODUCTION}

During studies of seizures induced by intraventricular ouabain in rats (Donaldson et al., 1971), it was noted that low doses of ouabain produced stereotyped behavior, similar to syndromes induced by apomorphine and amphetamine which have been associated with dopaminergic activity in striatum and the mesolimbic system. As it is of interest that experimentally induced inhibition of Na-K-ATP'ase by ouabain should result in stereotypy, this behavior was studied in groups of rats receiving 2, 3 and $4 \mu \mathrm{g}$ doses of ouabain administered intraventricularly, and in other groups pretreated with haloperidol, a butyrophenone which blocks dopamine (DA) receptors (Anden, 1970) and is known to inhibit stereotyped behaviour induced by amphetamine and apomorphine.

Ouabain inhibits Na-K-ATP'ase (Skou, 1965). After intraventricular administration, it is widely distributed in the brain where it is mainly bound to subcellular fractions rich in ATP'ase (Donaldson et al., 1972). The metabolic effects are complex. The transport of monoamines and aminoacids across membranes in vitro is inhibited (Tissari and Bogdanski, 1971; Pincus and Lee, 1973; De Belleroche and Bradford, 1972) and catecholamine metabolism is altered (Anagnoste and Goldstein, 1967; Goldstein et al., 1970; Ladisich, 1972). Because of this background of possible effects on neurotransmitter systems in vivo, the role of monoamines in the stereotyped behavior was studied. The effect of ouabain on monoamine turnover was estimated by measuring the concentration of dopamine (DA), norepinephrine (NE), and 5-hydroxytryptamine $(5 \mathrm{HT})$ in the striatum, hypothalamus, hippocampus, midbrain, and medulla oblongata in groups pretreated with $\alpha$-methyl-ptyrosine, which inhibits tyrosine hydroxylase (Spector et al., 1965).

\section{METHODS}

\section{Behavioral Siudies}

Female Sprague-Dawley rats (180$200 \mathrm{~g}$ ) kept under constant conditions of light, temperature, humidity, and Purina chow feedings were anaesthetised with sodium pentobarbitone $(60 \mathrm{mg} / \mathrm{kg}$, i.p.). Chronic, indwelling 25G cannula were inserted, as previously described (Donaldson et al., 1971), in the left lateral ventricle. Ouabain octahydrate (Sigma Co.) was freshly dissolved in artificial CSF, adjusted to $\mathrm{pH} 7.4$ by bubbling through the solution a mixture of $95 \%$ $\mathrm{O}_{2}-5 \% \mathrm{CO}_{2}$, and administered in doses of 2,3 , or $4 \mu \mathrm{g}$ in $50 \mu \mathrm{l}$ volume to groups of 6 rats for each dose $48 \mathrm{hr}$ after cannulation. The duration of injection was $2 \mathrm{~min}$ and observations were started at the end of the injections. Controls received CSF only. Additional groups were pretreated with haloperidol $1 \mathrm{mg} / \mathrm{kg}$ and $2.5 \mathrm{mg} / \mathrm{kg}$ i.p. $2 \mathrm{hr}$ before intraventricular ouabain $(3 \mu \mathrm{g})$. The animals were observed in circular wire-mesh cages $35 \mathrm{~cm}$ in diameter; pretreatment regimes were known to observers. The stereotyped behavior was rated at $5 \mathrm{~min}$ intervals for $50 \mathrm{~min}$, according to a scale modified from Ernst (1967): 0 = no gnawing; 1 = exaggerated sniffing, occasional licking; $2=$ repetitive licking, occasional biting; $3=$ frequent biting; $4=$ continuous gnawing. A non-parametric statistical evaluation was used. The percentage of rats reaching each point of the severity scale in sequential $5 \mathrm{~min}$ samples was calculated for each treatment group. The overall severity for each grade $(1,2,3,4)$ was calculated and the significance of differences 
between groups derived using the t-test for paired samples (Table 1).

\section{Catecholamine turnover study}

Four groups of rats with ventricular cannulae received treatment as follows: (1) control; intraventricular injection of CSF only, $50 \mu \mathrm{l}$ (2) intraventricular ouabain $3 \mu \mathrm{g}$ in $50 \mu \mathrm{l} \mathrm{CSF}$ (3) pretreatment with $250 \mathrm{mg} / \mathrm{kg} \mathrm{DL}$ methyl-p-tyrosine methyl ester $\mathrm{HCl}$ (4) $250 \mathrm{mg} / \mathrm{kg}$, i.p. $3.75 \mathrm{hr}$ before intraventricular ouabain $3 \mu \mathrm{g}$. Rats were sacrificed 10 min after intraventricular injection, the brains removed, and regional brain dissections performed (Glowinski and Iversen, 1966). Brain regions were stored in liquid nitrogen before biochemical analysis. Concentrations of DA, NE and 5HT were measured spectrofluorimetrically by the method of Butterworth et al. (1975a).

\section{RESULTS}

\section{Behavioral studies}

Intraventricular ouabain produced stereotyped behavior within $5 \mathrm{~min}$. The peak severity was $20 \mathrm{~min}$ and 30 $\min$ for 4 and $3 \mu \mathrm{g}$ doses, but a clear peak was not obtained for the less marked stereotypy at $2 \mu \mathrm{g}$ ouabain. The durations were 50,40 and $30 \mathrm{~min}$ for 4,3 and $2 \mu \mathrm{g}$ doses. There were significantly higher percentages
( $p<0.001$ ) for scores 2 and 3 with $3 \mu \mathrm{g}$ than with $2 \mu \mathrm{g}$ ouabain doses, and significantly higher percentages for grades 1,2 and 3 with $4 \mu \mathrm{g}$ doses. When gnawing occurred there was no excitation or increased locomotor activity.

Haloperidol $2.5 \mathrm{mg} / \mathrm{kg}$ significantly reduced the severity of stereotypy $(\mathrm{p}<0.05)$, shortened the duration from 40 to $30 \mathrm{~min}$, but did not delay the onset. Marked changes in posture occurred, with the animals lying prone with legs splayed behind while repetitively gnawing. Haloperidol $1 \mathrm{mg} / \mathrm{kg}$ did not alter the stereotypy significantly.

\section{Catecholamine turnover study}

The regional concentrations of DA, $5 \mathrm{HT}$ and NE in four groups of rats are shown in Table 2. Intraventricular ouabain produced significant reduction of NE concentration in the midbrain and hippocampus but not in the striatum. Pretreat ment with $\alpha$-methylp-tyrosine resulted in marked reduction of DA and NE in all brain regions as expected. When ouabain was administered to rats pretreated with $\alpha$-methyl-p-tyrosine, there was significantly less depletion of DA in the striatum and significantly more depletion of $\mathrm{NE}$ in the medulla oblongata than in control rats treated with $\alpha$-methyl-p-tyrosine but having intraventricular CSF only.

TABLE

The Behavioral Effects of Ouabain

\begin{tabular}{lc|c|c|c}
\hline \multicolumn{1}{c}{ DRUG REGIME } & \multicolumn{4}{c}{$\begin{array}{c}\text { STEREOTYPED BEHAVIOR } \\
\text { Mean Percentage } \pm \text { S.D. }\end{array}$} \\
\hline & 1 & 2 & 3 & 4 \\
Ouabain $2 \mu \mathrm{g}$ & $28 \pm 29$ & $10 \pm 11$ & $4 \pm 8$ & 0 \\
Ouabain $3 \mu \mathrm{g}$ & $41 \pm 32$ & $41 \pm 29^{\mathrm{a}}$ & $35 \pm 24^{\mathrm{a}}$ & $8 \pm 13$ \\
Ouabain $4 \mu \mathrm{g}$ & $51 \pm 30^{\mathrm{a}}$ & $51 \pm 30^{\mathrm{a}}$ & $46 \pm 34^{\mathrm{a}}$ & $7 \pm 15$ \\
$\quad$ Haloperidol $\mathrm{Img} / \mathrm{kg}$ & & & & \\
+ ouabain $3 \mu \mathrm{g}$ & $28 \pm 28$ & $28 \pm 28$ & $22 \pm 18$ & $7 \pm 9$ \\
$\quad$ Haloperidol $2,5 \mathrm{mg} / \mathrm{kg}$ & $16 \pm 16^{\mathrm{b}}$ & $16 \pm 16^{\mathrm{b}}$ & $16 \pm 16^{\mathrm{b}}$ & 0 \\
+ ouabain $3 \mu \mathrm{g}$ & & & \\
\hline
\end{tabular}

The behavioral effects of ouabain administered intraventricularly in doses of 2,3 and $4 \mu \mathrm{g}$, and the effect of pretreatment with haloperidol on the response to ouabain $3 \mu \mathrm{g}$. The mean of the percentages of rats achieving behavioral scores of $1,2,3$ and 4 provide an overall measure of behaviour, but with a large SD because it includes the peak and the end of the observation period. The significance of differences in behavior at different doses are estimated for each score in sequential 5 minute samples (t-test for paired samples).

a: significantly greater stereotypy than with $2 \mu \mathrm{g}(\mathrm{p}<0.001)$

b: significantly less stereotypy than with $3 \mu \mathrm{g}$ only $(\mathrm{p}<0.05)$

\section{DISCUSSION}

Intraventricular ouabain, in subconvulsant dosages of 2,3 and $4 \mu \mathrm{g}$ produces stereotyped behavior which is similar to that induced by apomorphine (Butterworth et al., 1975b) but lacking locomotor stimulation. This suggests that the mechanisms for sniffing, licking, and gnawing differ from those subserving locomotor stimulation. The reduction but not abolition of stereotypy by haloperidol, a DA-receptor blocker (Anden, 1970), at a dose which abolishes apomorphine induced stereotypy suggests that other mechanisms besides DA contribute to ouabain-induced stereotypyed behavior.

The complex biochemical effects of ouabain have been investigated in a variety of cellular systems in recent years (Skou, 1965). In addition to an increasing intracellular sodium and decreasing potassium, the concentration of intracellular calcium is increased (Stahl and Swanson, 1971) which is important because calcium has complex effects on the membrane potential during both resting and active phases (Koketsu, 1969) and on the mediation of the effects of biogenic amines (Phillis, 1974). Ouabain alters the transport of monoamines and aminoacids in vitro; it increases the release of NE from brain slices (Pincus and Lee, 1973), inhibits the uptake of tyrosine into brain slices (Goldstein et al., 1970) and the release of gluta mate, GABA, and aspartate from synaptosomes (De Belleroche and Bradford, 1972). Furthermore, as ouabain is bound to membranes rich in cholinesterases (Rodriguez de Lores Arnais et al., 1967) and impairs choline uptake into synaptosomes (Marchbanks, 1968), it may alter the transport of acetylcholine across membranes.

In these experiments the catecholamine turnover was estimated at 10 min. when stereotyped behavior was well established. Although $\alpha$-methylp-tyrosine uptake into the brain might be inhibited by ouabain, it was administered $3 / 4$ hours before ouabain, by which time its major metabolic effects would be established. Ouabain had no significant effect on the concentrations of dopamine in any brain 
region. NE concentration was diminished, however, in the mid-brain and hippocampus but not in the striatum, hypothalamus, or medulla. Ouabain could decrease NE concentration by effects on the synthesis, storage, intracellular metabolism, release or re-uptake of monoamines. Anagnoste and Goldstein (1967) have described inhibition of the conversion of ${ }^{14} \mathrm{C}$-DA to ${ }^{14} \mathrm{C}-\mathrm{NE}$ in the brainstem, hypothalamus, and cerebellum after intraventricular administration of ouabain.

A decrease in brain-stem NE after subdural ouabain (Ladisich, 1973) was accompanied by relative increase in deaminated metabolites, ${ }^{3} \mathrm{H}$-dihydroxymandelic acid, and ${ }^{3} \mathrm{H}$-dihydroxyphenylglycol, interpreted as an alteration in intracellular storage mechanism. Intraventricular ouabain in dogs and cats produces hypertension, tachycardia, and arrhythmias attributed to release of norepinephrine (Saxena and Bhargava, 1974). From our studies, the absence of a significant difference between control and ouabain-treated rats in the $\alpha$-methyl- p-tyrosine-treated group suggests that the reduction in concentration of $\mathrm{NE}$ in the midbrain or hippocampus is not due to enhanced release or diminished re-uptake. However, in the medulla the significant increase in NE-release after $\alpha$-methyl-p-tyrosine pretreatment suggests that ouabain may enhance amine release or block its reuptake at this site.

Ouabain inhibited DA-turnover in the striatum, suggests impaired release or enhanced re-uptake. The occurrence of reduced DA turnover concomitantly with stereotyped gnawing is surprising, but there are three possible explanations. Mesolimbic rather than striatal projections of dopaminergic pathways may be important in stereotyped movement (Costall and Naylor, 1973), with projections to tuberculum olfactorium (McKenzie, 1972), nucleus accumbens (Pijnenburg and Van Rossum, 1973), and the nucleus amygdaloideus centralis (Costall and Naylor, 1974). Secondly, the widely distributed ouabain may enhance 5-HT mechanisms which are inhibitory to stereotyped behavior (Grabowska et al., 1973; Weiner et al., 1973) or inhibit cholinergic mechanisms (Arnfred and Randrup, 1968; Klawans et al., 1972). A third explanation is that ouabain may primarily increase the sensitivity of dopaminergic receptors so that the reduction of DA turnover may be a result of feedback inhibition of the presynaptic nerve ending.

Stereotyped gnawing behavior, therefore, occurs in association with complex monoamine changes characterised by reduction in concentrations of hippocampal and midbrain NE, increase in turnover of NE with medulla oblongata, and reduction in turnover of DA in the striatum.

An experimental model in which impaired membrane transport, altered monoamine turnover, and stereotypy occur may be relevant to clinical studies. Clinical equivalents of stereotypy have been proposed for the affective disorders (M.R.C. Metabolic Unit, 1972) in which there is altered $\mathrm{Na}^{+}$and $\mathrm{K}^{+}$distribution, (Coppen and Shaw, 1963) and transport (Glen et al., 1968). Amphetamine-induced stereo-

TABLE 2

Effect of Ouabain on Catecholamine Turnover and 5-HT Concentration:

Concentrations of DA, NE, $5 H T$ in Brain Regions after Intraventricular Ouabain or CSF only, in Controls and after Pre-Treatment with $\alpha$-Methyl-p-tyrosine ( \pm S.E.)

\begin{tabular}{|c|c|c|c|c|c|}
\hline REGION & TREATMENT & $\mathbf{N}$ & $\mathrm{DA} \mu \mathrm{g} / \mathrm{g}$ & $N E_{\mu g} / g$ & $5 H T \mu g / g$ \\
\hline STRIATUM & $\begin{array}{l}\mathrm{CSF} \\
\mathrm{CSF}+\text { ouabain } \\
\alpha \mathrm{MpT}+\mathrm{CSF} \\
\alpha \mathrm{MpT}+\text { ouabain }\end{array}$ & $\begin{array}{l}5 \\
5 \\
5 \\
4\end{array}$ & $\begin{array}{l}7.34 \pm 0.48 \\
8.04 \pm 0.35 \\
2.11 \pm 0.20 \\
3.17 \pm 0.28^{b}\end{array}$ & $\begin{array}{l}0.47 \pm 0.03 \\
0.49 \pm 0.03 \\
0.19 \pm 0.02 \\
0.20 \pm 0.01\end{array}$ & $\begin{array}{c}0.52 \pm 0.09 \\
\text { Not done } \\
0.57 \pm 0.04 \\
0.47 \pm 0.14\end{array}$ \\
\hline HIPPOCAMPUS & $\begin{array}{l}\mathrm{CSF} \\
\mathrm{CSF}+\text { ouabain } \\
\alpha \mathrm{MpT}+\mathrm{CSF} \\
\alpha \mathrm{MpT}+\text { ouabain }\end{array}$ & $\begin{array}{l}4 \\
5 \\
4 \\
4\end{array}$ & $\begin{array}{c}0.18 \pm 0.01 \\
0.20 \pm 0.02 \\
0 \\
0\end{array}$ & $\begin{array}{l}0.29 \pm 0.03 \\
0.19 \pm 0.02^{\mathrm{a}} \\
0.11 \pm 0.01 \\
0.09 \pm 0.01\end{array}$ & $\begin{array}{c}0.44 \pm 0.08 \\
\text { Not done } \\
0.45 \pm 0.01 \\
0.40 \pm 0.02\end{array}$ \\
\hline MIDBRAIN & $\begin{array}{l}\mathrm{CSF} \\
\mathrm{CSF}+\text { ouabain } \\
\alpha \mathrm{MpT}+\mathrm{CSF} \\
\alpha \mathrm{MpT}+\text { ouabain }\end{array}$ & $\begin{array}{l}5 \\
5 \\
5 \\
5\end{array}$ & $\begin{array}{c}0.15 \pm 0.02 \\
0.15 \pm 0.01 \\
0 \\
0\end{array}$ & $\begin{array}{l}0.43 \pm 0.02 \\
0.35 \pm 0.03^{\mathrm{a}} \\
0.24 \pm 0.02 \\
0.21 \pm 0.02\end{array}$ & $\begin{array}{l}0.67 \pm 0.10 \\
0.77 \pm 0.03 \\
0.70 \pm 0.11 \\
0.84 \pm 0.22\end{array}$ \\
\hline HYPOTHALAMUS & $\begin{array}{l}\mathrm{CSF} \\
\mathrm{CSF}+\text { ouabain } \\
\alpha \mathrm{MpT}+\mathrm{CSF} \\
\alpha \mathrm{MpT}+\text { ouabain }\end{array}$ & $\begin{array}{l}5 \\
5 \\
5 \\
5\end{array}$ & $\begin{array}{c}0.45 \pm 0.03 \\
0.43 \pm 0.05 \\
0 \\
0\end{array}$ & $\begin{array}{l}1.77 \pm 0.08 \\
1.72 \pm 0.14 \\
0.94 \pm 0.08 \\
1.17 \pm 0.13\end{array}$ & $\begin{array}{l}2.04 \pm 0.05 \\
1.88 \pm 0.13 \\
1.46 \pm 0.09 \\
1.28 \pm 0.10\end{array}$ \\
\hline MEDULLA OBLONGATA & $\begin{array}{l}\mathrm{CSF} \\
\mathrm{CSF}+\text { ouabain } \\
\alpha \mathrm{MpT}+\mathrm{CSF} \\
\alpha \mathrm{MpT}+\text { ouabain }\end{array}$ & $\begin{array}{l}5 \\
5 \\
5 \\
5\end{array}$ & $\begin{array}{c}0.13 \pm 0.01 \\
0.14 \pm 0.02 \\
0 \\
0\end{array}$ & $\begin{array}{l}0.52 \pm 0.02 \\
0.59 \pm 0.03 \\
0.34 \pm 0.02 \\
0.25 \pm 0.03^{\mathrm{b}}\end{array}$ & $\begin{array}{l}0.50 \pm 0.06 \\
0.65 \pm 0.04 \\
0.71 \pm 0.05 \\
0.65 \pm 0.09\end{array}$ \\
\hline
\end{tabular}


typed behavior has been proposed as a model for schizophrenia (Snyder, 1973). Membrane transport in schizophrenia has been studied only in erythrocytes with conflicting results (Seeman and O’Brien, 1963; Parker and Hoffman, 1964). Phenothiazine inhibits $\mathrm{Na}^{+}-\mathrm{K}^{+}$-ATP'ase (Jarnfelt, 1962), and it is possible that a permanent membrane change occurs in patients developing tardive dyskinesias in which DA mechanisms may be abnormal. There is impaired uptake of dopamine into platelets in Parkinson's disease (Barbeau et al., 1975), suggesting generalized membrane changes in this disorder. Therefore, the ouabain model, in which experimentally induced inhibition of $\mathrm{Na}^{+}-\mathrm{K}^{+}$-ATP'ase results in stereotyped gnawing behavior associated with complex monoamine changes, justifies further study of membrane transport mechanisms in these neurological and psychiatric disorders, in which distrubance of neurotransmitter function may occur.

\section{ACKNOWLEDGEMENTS}

The studies reported in this paper were supported through grants from the Medical Research Council of Canada ( $\left.M^{\top}-4938\right)$ and the $W$. Garficld Weston Foundation.

\section{REFERENCES}

ANAGNOSTE, B., and GOLDSTEIN, M. (1967): The effects of ouabain on catecholamine biosynthesis in different areas of rat's brain. Pharmacologist 9, 210 .

ANDEN. N. E., BUTCHER, S. G., CORRODI. H. FUXE, $K$., and UNGERSTEDT, $U$. (1970): Receptor activity and turnover of dopamine and noradrenaline after neuroIeptics. Eur. J. Pharmacol. 11, 303-314.

ARNFRED, T., RANDRUP. A. (1968): Cholinergic mechanisms in brain-inhibiting amphetamine-induced stereotyped behaviour. Acta Pharmacol. 26, 384-394.

BARBEAU, A., CAMPANELLA. G.. BUTTERWORTH, R. F. and YAMADA. K. (1975): Uptake and efflux of ${ }^{14} \mathrm{C}$ dopamine in platelets Evidence for a generalized defect in Parkinson's disease. Neurology 25. 1-9.
BUTTERWORTH. R. F.. LANDREVILLE, F., GUITARD, $M$., and BARBEAU, $A$. (1975): A reliable method for the simultaneous estimation of DA, NA and $5 \mathrm{HT}$ in discrete areas of brain. Clin. Biochem. 8 , 298-302.

BUTTER.WORTH, R. F., POIGNANT, J. C., and BARBEAU, A. (1975): Apomorphine and piribedil in rats: Biochemical and pharmacologic studies. Adv. Neurol. 9, 307310.

COPPEN, A. J. and SHAW, D. M. (1963): Mineral metabolism in melancholia. $\mathrm{Br}$. Med. J. 2, 1439.

COSTALL. B., and NAYLOR. R. J. (1973): The role of the telencephalic dopaminergic systems in the mediation of apomorphinestereotyped behaviour. Eur. J. Pharmacol. $24,8-28$

COSTALL, B., and NAYLOR, R. J. (1974): $A$ role for the amygdala in the development of the cataleptic and stereotypic actions of the narcotic agonists and antagonists in the rat. Psychopharmacologia 35, 203.

DE BELLEROCHE. J. S., and BRADFORD. H. F. (1972): Metabolism of beds of mammalian cortical synaptosomes: Response to depolarising influences. J. Neurochem. 19. 486-602.

DONALDSON, J., ST-PIERRE, T., MINNICH. J. L. and BARBEAU, A. (1971): Seizures in rats associated with divalent cation inhibition of Na-K-ATPase. Can. J. Biochem. 49, 1217-1224.

DONALDSON, J., MINNICH, J, L. and BARBEAU, A. (1972): Ouabain-induced scizures in rats: Regional and subcellular localisation of ${ }^{3} \mathrm{H}$-ouabain associated with Na-K-ATP'ase in brain. Can. J. Biochem. 50, 888-896.

ERNST, A. M. (1967): Mode of action of apomorphine and dexamphetaminc on gnawing compulsion in the rat. Psychopharmacologia $10,316-323$.

GLEN, A. I. M. ONGLEY.G. C.. and ROBINSON, K. (1968): Diminished membrane transport in manic-depressive psychosis and recurrent depression. Lancet 2, 241-243.

GLOWINSK I, J., and IVERSEN, L. L. (1966): Regional studies of catecholamines in the rat brain -1 . The disposition of $\left({ }^{3} \mathrm{H}\right)$ norepinephrine. $\left({ }^{3} \mathrm{H}\right)$ dopamine and $\left({ }^{3} \mathrm{H}\right)$ dopa in various regions of the brain. J. Neurochem. 13, 655-669.

GOLDSTEIN, M., OHI, Y., and BACKSTROM, T. (1970): The effects of ouabain on catecholamine biosynthesis in rat brain cortex slices. J. Pharmacol. Exp. Ther. 174. $77-82$.

GRABOWSKA, M., ANTKIEWICZ, L., MAJ, J., and MICHALUK, J. (197.3): Apomorphine and central serotonin neurons. Pol. J. Pharmacol. Pharm. 25, 29-39.

JARNFELT, J. (1962): Properties and possible mechanisms of $\mathrm{Na}^{+}$and $\mathrm{K}^{+}$-stimulated microsomal adenosinetriphosphatase. Biochim. Biophys. Acta 59, 643-654.
KLAWANS, H. L.. RUBOVITS, R.. RINGEL, S. P., and WEINER, W. J. (1972): Cholinergic and anticholinergic influence on amphetamine-induced stereotyped behaviour. J. Neurol. Sci. 17, 303-308.

KOKETSU, K. (1969): Calcium and the excitable cell membrane. Neurosci. Res. 2, 1-39.

McKENZIE. G. M. (1972): The role of the tuberculum olfactorium in stereotyped behaviour induced by apomorphine in the rat. Psychopharmacologia 23, 212-219.

MEDICAL RESEARCH COUNCIL BRAIN METABOLISM UNIT (1972): Modified amine hypothesis for the etiology of affective illness. Lancet ii. 573-577.

PARKER, J. C., and HOFFMAN, J. F. (1964): Failure to find increased sodium potassium ATP'ase in red cell ghosts of schizophrenics. Nature 201, 823.

PHILLIS, J. W. (1974): The role of calcium in the central effects of biogenic amines. Life Sci. 14, 1189-1201.

PIJNENBURG, A. J. J., and VAN ROSSUM, J. M. (1973): Stimulation of locomotor activity following injection of dopamine into the nucleus accumbens. J. Pharm. Pharmacol. 25, 1003-1004.

PINCUS, J. H., and LEE, S. H. (1973): Diphenylhydantoin and calcium. Arch. Neurol. 29. 239-244.

RODRIGUEZ de LORES ARNAIS, G., ALBERICI. M., and DE ROBERTIS, E. (1967): Ultrastructural and enzymic studies of cholinergic synaptic membrane. J. Neurochem. 14, 215-225.

SEEMAN, P. M., and O'BRIEN, E. (1963): Sodium-potassium-activated adenosine triphosphatase in schizophrenic erythrocytes. Nature 200. 263-264.

SKOU, J. C. (1965): Enzymatic basis for active transport of $\mathrm{Na}^{+}$and $\mathrm{K}^{+}$across cell membrane. Physiol. Rev. 46, 596-615.

SNYDER, S. H. (1973): Amphetamine psychosis: A "model" schizophrenia mediated by catecholamines. Am. J. Psychiatry 130. $61-67$.

SPECTOR, S., SJOERDSMA. A., and UDENFRIEND. S. (1965): Blockade of endogenous norepinephrine system by $\alpha$ methyl-tyrosine, an inhibitor of tyrosine hydroxylase. J. Pharmacol. Exp. Ther. 147. $88-95$.

SAXENA, P, R., and BHARGAVA, K. (1974): Central beta-adrenoceptor sites and ouabain action. Pharmacol. Res. Commun. 6. 347. 355 .

STAHL. W. L., and SWANSON. P. D. (1971): Movements of calcium and other cations in isolated cerebral tissues. J. Neurochem. 18. 415-427.

TISSARI, A. H., and BOGDANSKI, D. F. (1971): Biogenic amine transport. VI. Comparison of the effects of ouabain and $\mathrm{K}^{+}$ deficiency on the transport of 5-hydroxytryptamine and norepinephrine by synapiosomes. Pharmacology 5, 225-234. 